Citation: Kyseliuk, N., Hubina, A., Martyniuk, A., \& Tryndiuk, V. (2020). Non-verbal means of communication in the representation of the emotional state of joy in modern English fictional discourse. Cognitive Studies / Études cognitives, 2020(20), Article 2284. https://doi. org/10.11649/cs.2284

\section{NATALIA KYSELIUK}

Lutsk National Technical University, Lutsk, Ukraine

https://orcid.org/0000-0002-8401-8579

kyselyuk@ukr.net

\section{ALLA MARTYNIUK}

Lutsk National Technical University, Lutsk, Ukraine

https://orcid.org/0000-0002-5979-3936

alla-mart@ukr.net

\author{
ALLA HUBINA \\ Lutsk National Technical University, Lutsk, \\ Ukraine \\ https://orcid.org/0000-0002-8966-9581 \\ hubinaalla@ukr.net
}

\author{
VALENTYNA TRYNDIUK \\ Lutsk Pedagogical College, Lutsk, \\ Ukraine \\ https://orcid.org/0000-0002-8326-3740 \\ tryndiuk_va@ukr.net
}

\title{
NON-VERBAL MEANS OF COMMUNICATION IN THE REPRESENTATION OF THE EMOTIONAL STATE OF JOY IN MODERN ENGLISH FICTIONAL DISCOURSE
}

\begin{abstract}
This article concerns the study of the non-verbal means of communication designating the emotional state of joy which are present in fictional discourse. The functional peculiarities of non-verbal means designating the emotional state of joy are specified. It is proved that the register of nonverbal components indicating joy includes facial expressions, gestures, phonation, and the like. The subsystems of kinesic and phonatory non-verbal components are the dominant ones. Fictional discourse including representations of joy contains both verbal and non-verbal means of designating the emotional state, functioning either separately or in interaction. This interaction is based on the concept of emotional valence and is represented in repetition, contradiction, substitution, complementation, emphasis and regulation. In an utterance, non-verbal means can occur in the initial, medial, and final positions. The most common models of the occurrence of non-verbal components denoting joy in utterances are revealed.

Keywords: emotional state of joy; fictional discourse; verbal means; non-verbal means of communication; communicative interaction; communicative function
\end{abstract}

\section{Introduction}

Emotions permeate the entire communicative activity of an individual and all areas of his/her life. They are reflected at all levels of language. The most important form of expression of human emotions is speech. Although the expression of emotional states in speech is extremely variable, human communication proves that all emotional states can be correctly recognized by speakers. 
Non-verbal means of communication in the representation of the emotional state of ...

Literary fiction contains the representation of different emotional states. It describes emotional categorical situations, the verbal and non-verbal behaviour of an individual, the means of emotional communication, as well as the emotional experience of an individual.

The object of the present research is the emotional state of joy. It can be represented not only by linguistic means, or 'verbally', but also by non-linguistic means (Kyseliuk, 2006). Joy cannot be analysed without taking into account non-verbal components, as these reveal the speaker's emotions. These components are just as significant, mandatory and necessary as verbal elements. They contribute to a complete and adequate understanding of the utterance because the emotional aspect of the speech is revealed. The non-verbal components of communication that express the emotional state of joy of interlocutors in fictional discourse are represented by nominations in the author's remarks.

In modern linguistics, non-verbal means are defined as means of non-verbal communication involved in a communicative act (Streek \& Knapp, 1992). Since kinesic, proxemic and phonational components of communication all belong to the system of non-verbal means of communication (Ekman \& Friesen, 1981, p. 58), the term non-verbal components of communication (NVCs) will be used henceforth in this paper. It should be noted that this term has a broader meaning than the term 'body language' because it includes phonational components (tone, timbre, tempo, volume and other prosodic features), in addition to kinesic components (mimics and gestures).

Due to its polysemantic character, any non-verbal sign simultaneously carries information about both the speaker's personality and about his attitude to the interlocutor (Koziarevych, 2006 , p. 75). In other words, the inner world of a person is revealed through his non-verbal behaviour. Hence, non-verbal components appear to be indicators of the communicant's opinions, his attitude to events, the world around him, and his relationships with other communicants.

It is the non-verbal component that can indicate a discrepancy in such postulates of speech communication as the postulate of quality, because the evaluation of the utterance in this regard involves comparing the semantics of the verbal information with the content obtained through other channels. The discrepancy between non-verbal means of communication and the verbal part of an utterance, as well as the polysemy of gesture signs, are the cause of communicative failures caused by non-verbal factors. The success or failure of communication depends largely on nonverbal components (Kreĭdlin \& Krongauz, 2015).

The significance of non-verbal components is also proved by the fact that the verbal part of a message can be interpreted completely differently due to the accompanying non-verbal components of communication. The results of this may even be contraversive (Kyseliuk, 2006, p. 16). Quite often, this double interpretation is possible only because NVCs denote the opposite meaning. This proves the extremely wide range of NVCs' capabilities.

\section{The representation of non-verbal phenomena in text}

The important role played by non-verbal means of communication is also reflected in fictional discourse. In order to expound a text more perfectly, it is important to pay attention not only to the words of the characters, but also to the way (how?) and the reasons (why?) they speak (Adanakova, 1989, p. 17; Poyatos, 1997a, pp. 17-47; Soloshchuk, 2013). The answers to these last two questions are very often found in the literary representation of non-verbal phenomena in the text. It should be mentioned that kinesic phenomena are the most studied in literary texts, since the amount of gesture nominations in fiction is very significant.

Gestures are difficult to verbalize and in a literary text the author does not only convey the character's speech, but literarily describes it, including non-verbal aspects of the speaker's behaviour, stylistically consistent with verbal speech (Poyatos, 1997a, p. 18). Both non-verbal components and their descriptions in the text are transmitted by the linguistic semiotic system, which acts as a metalanguage of the non-verbal semiotic system. According to V. I. Adanakova, verbalized NVCs in literary texts function as specific signs, which reflect phenomena-signs whose 
referents are signs of a non-verbal system with its own meaning (Adanakova, 1989, p. 5).

Since each element in a text has a certain functional, literary, stylistic, semantic, and pragmatic meaning, the criteria for selecting gestures are rather strict. Both spontaneous, non-verbal communicative components, and occasional, informative NVCs, which are meaningful for the reader, become equally important and significant.

Researchers treat the manifestation of emotional states by means of NVCs as the main role of non-verbal means in a text. When combined with a replica, NVCs cause the compression of several thoughts and stimulate the reader's associative perception, leading to an understanding of certain content. Therefore, in a piece of fiction, physical movement is always well-reasoned. The author uses the description of a particular NVC for a specific purpose. This means that this gesture is not accidental and contains important information for the reader. Thus, a literary text is a rather reliable source for analysis, since it already presents verbalized NVCs. Moreover, the very fact of using the description of these non-verbal means proves their significance in the process of communication.

\section{The non-verbal representation of the emotional state of joy}

Since NVCs representing the emotional state of joy are signs, they have a plane of content and a plane of expression. For example, the NVC whose form can be represented as to do a victory dance, is an expression of joy. Non-verbal signs can also be represented in two ways in verbal descriptions. In other words, the meaning can reflect both the form (with different details) and the content of the NVC. Verbal descriptions that render the form of the NVC are called somatic (for example: to slap sb. a high five, to swing sb. into the air, to give sb. a tight fist, to start squinting, to slow down the tears etc.). Descriptions that convey the content plane of the NVC are called sensual (for example: to cry triumphantly, to shake one's head in amazement, to give sb. a quick, bright look - almost of adoration etc.).

According to the results of the present research, the NVCs which represent 'joy' can be conveyed by both somatic and sensual descriptions. However, sensual descriptions prevail in the context of a subtle difference of gestures and facial expressions, as well as when the gesture is complex and multi-compound. There are also somatic-sensual descriptions of NVCs to denote the emotional state of joy. They harmonize the description of the form of a certain NVC with its meaning (for example: to run joyfully, to smile in happiness, to curl up in happiness, to nod at sb. happily, to sigh with happiness and so on).

Regarding the means of NVC nomination that convey joy, the encoding of the form and content of the NVC can be performed in different ways. This can be a word (for example: to smile, to laugh, to cry, to giggle, to jump), phrases (for example: to give a hug, to slap sb.'s back a couple of times, to give a smile etc.) and sentences (for example: one's face goes quite pink with pleasure; one's teeth burst through one's skin, white-petalled and happy etc.).

It should be noted that when conveying gesture-and-mimic NVCs denoting joy by language means, the way of conveying that movement (i.e. the form of the NVC) is more essential. The main role in the verbal presentation of non-verbal means denoting movements and actions is performed by verb combinations, represented by various structures (for example: to push one's glasses back up the bridge of one's nose, to say with a laugh, to shout lifting one's arms, etc.).

Phonatory NVCs actualizing the emotional state of joy are based on the features that convey the nature of the sound and indicate the volume of the voice (to say in a low voice, in a whisper; to say aloud), the sound quality (to say "Yes" with lots of sibilance), its pitch level (in a shrill), or emotional changes in the voice (in a trembling voice, to say in admiration). Phonatory NVCs representing joy are quite often conveyed by means of phrases consisting of a verb that indicates speech and its closer definition (for example: to say brightly, to say lightly, and so on). 
Non-verbal means of communication in the representation of the emotional state of ...

Regarding proxemic components, they are manifested verbally only in the most general sense when indicating the emotional state of joy and the presence of the addressee's relevant background knowledge should also be taken into account. In such cases, interpersonal distances, the location and positions of communicants in space, changes in these positions, and so on can be specified (for example: to come up to someone, to lean closer). This is also relevant when conveying nonverbal symptoms, which also include external signs of psychologically significant states: tears, changes in the colour of the face (redness), etc. (for example: to burst into tears, one's cheeks getting redder, one's cheeks burned, etc.). By their nature, such NVCs are symptomatic and are not used independently. As a rule, they accompany kinesic or phonatory components denoting joy, enhancing their meaning.

The obtained results lead to the conclusion that among the various NVCs verbalized in text to indicate the emotional state of joy, the most common way of nominating non-verbal means is not a single word, but instead the use of phrases. This can be explained by the fact that the verbalization of non-verbal components is performed by transcoding messages from signs of one system into signs of another. This transcoding occurs because there is no correspondence of semantically discrete units of one code to units, or their combinations, of other codes. In this case, a certain amount of information is lost, since the actual number of non-verbal components is much greater than is reflected in the description.

Despite the fact that a number of verbal descriptions of the emotional state of joy allow both the form and content of the NVC to be assessed, in most cases either a form or a content is represented. If only the form of the NVC is represented by author, it is necessary to consult the dictionary to specify its meaning. When analysing the NVC system in English discourse, it must be said that at present there does not exist a dictionary in which all non-verbal components are fully and specifically represented. In most cases, kinesic NVCs are subject to description. Therefore, to determine the form and boundaries of the meaning of NVCs that express joy, various sources were used, including author's interpretations in literary texts, which focus not only on the form of the NVC, but also on its content. Dictionaries and scientific papers were also used.

Difficulties in determining whether it is the same or different NVC denoting joy arise when the same movement or gesture in a literary text is represented in different ways. The lexemes in the verbal description may appear without change, or with changes in style attributes (for example: to exclaim / to give a cry). The description can also show the differing intensity of the same NVC (for example: to give a happy smile / to be all smiles). Different descriptions are also possible when the author uses common language or individual author descriptions (for example, to chirp / to say joyously).

These difficulties were solved by analysing the dictionary definitions of verbal descriptions. For example, the descriptions of kinesic NVCs to hug, to embrace, to put one's arms around someone, to throw one's arms around someone can be rendered as descriptions of one or more NVCs. An analysis of their semantics reveals their semantic proximity. The Oxford Paperback Thesaurus Dictionary, for example, says that to embrace is synonymous with to hug (Waite, 2012, p. 258). The London Language Activator Dictionary contains the following definitions of these words: to hug - "to put your arms around someone and hold them (underlined by the authors) close to you, especially to show that you love them or to comfort them" and to embrace - "to put your arms around someone and hold them (underlined by the authors) in a friendly or lovingly way, especially when you are meeting or leaving someone" (Longman language activator, 1996, p. 627). These definitions justify including the description to put one's arms around someone in this group. Moreover, the description to throw one's arms around someone was also attached to the same group as it differs from the previous description only in its degree of intensity. Taking into consideration their established semantic proximity, it can be concluded that all these descriptions are descriptions of the same NVC - "to hug someone", which is quite often a manifestation of joy.

Another problem, however, stems from the fact that the descriptions of different NVCs may coincide. For example, to shake one's head represents, on the one hand, the NVC "to turn quickly 
one's head from side to side several times", which expresses admiration or surprise, and on the other hand, it represents the NVC "not very quickly tilt one's head to the right, then to the left shoulder several times", which means discontent, or a critical attitude to something. In such cases, context is important. Due to the fact that in the following example this NVC is accompanied by the author's remark containing the word "happily", it may be supposed the first of the two aforementioned meanings applies. For example:

(1) "Gets where?" Eleanor shook her head at them feeling her lovely heavy hair around her face. "Gets where?" she asked happily (Jackson, 1959, p. 238).

When it comes to proxemic NVCs and non-verbal symptoms that indicate joy, the problem of identifying NVCs is solved in the same manner.

Unlike kinesic NVCs, phonatory components denoting the emotional state of joy do not give a detailed description of the form, which corresponds to its meaning. This is due to difficulties in identifying phonation variants. Therefore, in fictional discourse such non-verbal components are mainly represented by sensual descriptions, that is, they reflect the meaning of the NVC, but not its form. By means of phonatory NVCs, many different tones and nuances may be added to a message. All this diversity is reflected in the variety of their descriptions. For example, authors convey the phonatory NVC "to speak joyfully" by verbal means in different ways, taking into account certain peculiarities: to say brightly, to say happily, to say joyously, and so on. As a result, as in the case of kinesic NVCs, some difficulties arise in determining whether the same phonatory component or a different NVC is being described. It is also difficult to establish boundaries between subtle differences. In this case, it may be preferable to focus on a subgroup of phonatory components united by a main meaning, rather than on individual NVCs. Such subgroups are usually revealed by analysing dictionary definitions.

In addition, some phonatory means are strictly phonatory NVCs (for example, to laugh, to whisper, to scream and so on), and other NVCs are examples of syncretism, meaning that the elements are inseparable and homogeneous. For example, verbal descriptions such as to say brightly, to say happily and so on do not only describe phonatory characteristics, but also reflect the participation of other types of non-verbal components denoting joy, mainly kinesic NVCs. However, due to the fact that these elements are inseparable and are presented by a verb of saying, they are considered to be phonatory NVCs. Only a small part of the descriptions of phonatory NVCs conveying joy gives an idea of their form, reflecting, in fact, their phonatory parameters (speech tempo, voice pitch modulation, etc.). The rest of the description reflects the meaning of the phonatory NVCs.

\section{Results}

The analysis of verbal descriptions of non-verbal components in the studied corpus of literary texts revealed a system of NVCs denoting the emotional state of joy. This system consists of 284 elements, represented as percentages as follows:

- kinesic NVCs - 48\%;

- phonatory NVCs - 38\%;

- non-verbal symptoms - 8\%;

- proxemic NVCs - 6\%.

According to linguistics, the system of non-verbal means of communication includes three types of phenomena: 1. phonatory, meaning sound parameters of speech which are superimposed on the formant and intonation structure of the utterance (speech tempo, pitch, volume, rhythm; vocalizations such as laughter, shouting, moaning, whining, and so on); 2. kinesic (these include 
Non-verbal means of communication in the representation of the emotional state of ...

communicatory significant gestures, facial expressions, body movements, poses, gait etc.); 3. proxemic, meaning communicatively significant spatial parameters of human behaviour (the distance between communicants, the position of the speaker's body towards the interlocutor). Non-verbal symptoms have also been included in this system for the purposes of the present study. These components, according to F. Poyatos, are communicatively significant chemical and dermal reactions (Poyatos, 1997b, p. 252).

It should be noted that non-verbal components can be either inherent or acquired. In the case of acquired NVCs, their value is culturally and socially determined (Piz, 2000, p. 12). Therefore, when studying the representation of the emotional state of joy in English fictional discourse, it is necessary to consider the peculiarities of the communicants' education. For example, a smile in many cases is not an indicator of joy or happiness, but only a sign of politeness, as in the phrase "Glad to see you".

According to R. Krause and K. Tuite, gestures accompanying a conversation, with the exception of stereotypic and conventional gestures, do not so much perform a communicative function as they help the speaker make a coherent speech, facilitating the recall of words from verbal memory (Krause, 2001; Tuite, 1993, pp. 83-105). This view cannot be fully accepted, since even unconventional gestures in a certain context contribute to the correct interpretation of behaviour.

As the factual material proves, the range of non-verbal means to indicate joy is quite wide:

(2) The moment Diana saw me she excused herself and hurried forward, a wide smile lighting up her face, her pale grey-blue eyes reflecting the same kind of eagerness and joy which I usually associate with Andrew. He always has that same happy, anticipatory look when he is seeing me for the first time after we've been apart; it is spontaneous, and so very loving.

'Darling, you're here! I can't believe it, and it's such a lovely surprise, I'm so happy to see you!' Diana cried, grasping my arm (Bradford, 1995, p. 119).

In this example, the emotional state of joy is represented by both verbal and non-verbal means, namely: kinesic (a wide smile lighting up her face, happy look, grasping my arm), proxemic (hurried forward), phonatory non-verbal components (cried), and non-verbal symptoms (eyes reflecting joy).

Taking into account all of the aforesaid, the manifestation of the emotional state of joy will now be considered in terms of kinesic, proxemic, and phonatory NVCs, and non-verbal symptoms. The manner in which these NVCs are verbalized in English fiction will be explored.

In the process of communication, verbal and non-verbal components interact with each other. A combinatorial group of non-verbal and verbal means of communication has the following manifestations: repetition (a duplication of verbal means by nonverbal ones); contradiction (their semantic opposition); substitution (a replacement of verbal means by kinemes); complementation, emphasis (an increase in attention due to non-verbal components of communication); regulation (a promotion of interactivity of the speaker and the addressee, etc.) (Selivanova, 2006, p. 442).

Verbal and non-verbal means that express the emotional state of joy interact in discourse. Therefore, there are good reasons to investigate the functional focus of these components. It is important because these components, denoting the emotional attitude of the speaker, actualize the pragmatic function of an utterance. According to the results of the present research, the emotive valence (i.e. the ability to interact) of verbal and non-verbal means that express the emotional state of joy is actualized in:

- repetition, when a non-verbal component does not carry any additional information about the content of a verbal message, but merely duplicates it:

(3) Her smile was ecstatic. "It is a good plan, kinsman, it will work!" (G. Harris, 1984, p. 170).

- contradiction, when non-verbal behaviour is contrary to verbal behaviour: 
Non-verbal means of communication in the representation of the emotional state of ...

(4) Bolitho smiled. 'You'd disobey your commodore, Mr. Veitch? In time of war it could hang you!'

They both laughed (Kent, 1976, p. 215).

(5) A year after the separation my mother had telephoned to announce that she was going to have a baby. "A baby!" I had said incredulously. "How could you?" She had laughed (Livesey, 1990, p. 172).

- substitution, when non-verbal means substitute verbal ones:

(6) Abandoning a lifelong belief that to name happiness is to dissipate it, she smiled at herself in the mirror and told herself silently, "Your measure of happiness" (Jackson, 1959, pp. 136-137).

- emphasis, when NVCs that express joy make the utterance more emphatic:

(7) “Oh, well done!" cried Professor Flitwick, clapping. "Everyone see here, Miss Granger's done it!" (Rowling, 1999, p. 66).

- regulation, when non-verbal means promote communication between people:

(8) “Oh, yes!" said David and Flamenko simultaneously. David smiled at Flamenko, who smiled at Professor Slade, who smiled at me (Gonick, 1983, p. 55).

When expressing the emotional state of joy, verbal and non-verbal means of communication interact with each other and form certain configurations:

[i] non-verbal + verbal (non-verbal means complement verbal ones and create the emotional background of the conversation). For example:

(9) Clarmont grinned. 'You'll see. You'll love this' he announced, jumping down from his cab (J. Harris, 2001, p. 163).

As the above example shows, the non-verbal component, which indicates joy, precedes the verbal part of the message. It creates an emotional climate and increases the expressiveness of the speech, as well as providing feedback.

[ii] verbal + non-verbal (non-verbal components explain and emphasize the verbal part of the message). For example:

(10) 'Stuff the assignment!' he shouted merrily. To emphasize his words he slapped the heavy duffel bag standing on his $\overline{\text { desk, and }}$ it gave out the unmistakable sound of bottles clinking together. Jay turned back to the class feeling almost delirious (J. Harris, 2001, p. 51).

[iii] non-verbal + verbal + non-verbal (this combination creates an emotive frame for the utterance). For example:

(11) Jay nodded. 'Great. I mean...'

She flashed him one of her rare warm smiles (J. Harris, 2001, p. 306).

[iv] verbal + non-verbal + verbal (non-verbal means emphasize the speaker's emotional state).

For example:

(12) "She said that she liked living with me - with us, that is." He smiled. "I was so glad. All along I've had the feeling that she was unhappy here and that I was just a poor substitute for Helen. Now, it's clear that she thinks of this as her home." (Livesey, 1990, p. 316). 
As these examples demonstrate, the non-verbal component denoting joy can be in the initial, medial or final position.

If NVCs denoting joy are in the medial or final position in relation to the verbal components, they enlarge and duplicate the content of the verbal message. When an NVC denoting joy is in the initial position, it creates an emotional background for the entire message, transmitting the emotional state of joy. Furthermore, it determines that the intentions of the previous speaker are introduced and established. In this combination of non-verbal and verbal means of representing joy, the non-verbal component precedes the verbal message, informing and warning the recipient about the content of the verbal part of the utterance.

The illustrative material has proved that the dominant constructions are those in which the verbal components occupy an initial position. The combination of verbal and non-verbal components models the illocutionary power of expressing joy.

Non-verbal components that express joy accompany the verbal part of the message and perform the following basic functions during interaction:

[i] The function of support of the verbal component (see Fig. 1) is shown in the vector unidirectionality of the intentional direction of non-verbal and verbal messages. It can be illustrated by the following example:

"Oh, hello there!" He called, beaming around at the assembled students. (Rowling, 2002, p. 34).

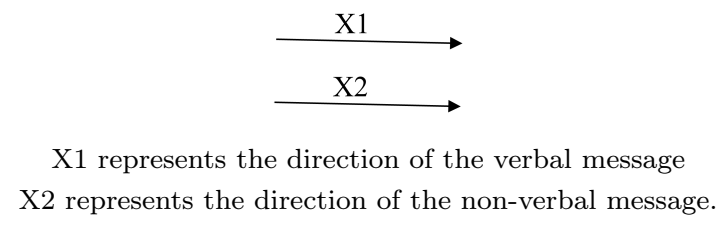

Figure 1: Function of support

The function of support is actualized when a verbal component of communication is supported by a non-verbal one. In this case, a one-way vector direction of both verbal and non-verbal meanings can be observed. The use of NVCs as a support tool in order to confirm the meaning of the verbal component of an utterance allows the communicant to achieve a high level of expressiveness and to fill the message with the desired strength and effectiveness.

[ii] The function of identifying the intentional direction of the verbal component (see Fig. 2) is manifested in the vector multi-directionality of non-verbal and verbal messages

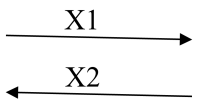

Figure 2: Function of identifying

If a non-verbal component performs the function of identifying the intentional direction of a verbal component, the opposite vector direction of their meanings can be observed. The nonverbal and verbal messages are in semantic contradiction, thus forming semantic dissonance. At the same time, the non-verbal message does not adjust its meaning to the verbal one, but identifies its real intentional direction. If words and gestures are not congruent, the speaker trusts non-verbal communication more. Therefore, in the following example the speaker expresses his indignation, which is realized at the level of verbal means. At the same time, his non-verbal action (smiled up at him) comes into conflict with the statement. The intention of expressing joy, which is not supported verbally, is identified by non-verbal means: 
Non-verbal means of communication in the representation of the emotional state of ...

(14) 'Oh you! You're impossible! Incorrigible!' But despite my words, I smiled up at him (Bradford, 1995, p. 99).

In dialogic discourse, speakers often use unextended verbal statements which are grammatically arranged as simple or even elliptical sentences, especially in spontaneous, emotional speech. A. D. Belova notes that the influence of emotions on speech manifests itself in the 'degradation' of abstract thought and a transition to the simplest lexical units and grammatical constructions (Belova, 1997). Such "simplest lexical units and constructions" do not carry full communicative information. They are usually represented only by a part of the utterance (a separate lexical unit, an elliptical construction) that contains an incomplete statement, or by a simple unextended sentence, the content of which is not commented on by the speaker (Kolokol'tseva, 2001). In such communicative situations, it is the non-verbal behaviour of the communicant that plays a key role, since it performs the function of actualization, explanation and supplementation of the information contained in the verbal message (Streek \& Knapp, 1992). In this case, non-verbal means of communication perform the function of extending the meaning of a verbal message. (see Fig. $3)$ :

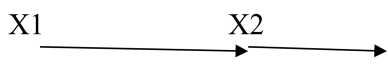

Figure 3: Function of extending

Extending can be performed both by highlighting a verbal message:

'Wonderful.' Jay grinned and tipped the wineglass at her (J. Harris, 2001, p. 19).

(16) 'Arnie's been offered a contract with Borough Football Club for next season,' she said, swelling with pride. $\langle\ldots\rangle$

'Wow!' said John.

'Oh, Arnie, well done, son,' said his mother, getting up and going over to him to smack a kiss on his cheek, her eyes glistening with tears (Evans, 1998, p. 47),

and by transmitting information that is not contained in the verbal component:

(17) "I have a friend?" said Mr Eborebelosa, beaming all at once. He capered about for a moment (Bradbury, 1962, p. 36).

In examples ( $15 \& 16)$, the verbal expression of the emotional state of joy is extended by a large number of non-verbal components. In example (17), the speaker's expression of joy at the appearance of a new friend occurs exclusively by non-verbal means (said, beaming; capped about).

\section{Conclusion}

Summarising the results of this study, it has been revealed that subsystems of kinesic and phonatory non-verbal components are dominant in the expression of the emotional state of joy. They play a central role in communication when actualizing the emotional state of joy. The nominations of these NVCs are represented most of all in literary texts. The description of the emotional state of joy can be accompanied by the nomination of two or more non-verbal components (for example, kinesic NVC nominations can be used together with phonatory NVC nominations, etc.). The interpretation of joy is possible due to an understanding of the contextual environment of the verbalized NVC and the verbal means of this emotional state. Verbal and non-verbal components denoting joy interact and complete each other, as well as functioning autonomously in order to 
express the emotional state of joy. The intensity of the expression of joy is achieved through the interaction of non-verbal and verbal means of communication.

Participating in the actualization of the emotional state of joy, NVCs can take different positions in the structure of dialogue discourse: 1) initial; 2) medial, 3) final. In the initial position, non-verbal components precede the verbal part of the utterance, increasing the expressiveness of the speech and creating an emotional basis for the verbal part of the message. In the medial position, non-verbal means of actualization of joy accompany and clarify the content of the verbal message, thereby confirming its accuracy and strengthening the semantic meaning of words. In the final position, non-verbal means complete a verbal message and support it.

\section{References}

Adanakova, V. I. (1989). Stilisticheskiて potentsial kinematicheskikh recheniu v angliı̌skom khudozhestvennom tekste [Unpublished summary of doctoral dissertation]. Leningradskiǔ gosudarstvennyı̌ pedagogicheskiu institut im. A. I. Gertsena.

Belova, A. D. (1997). Lingvisticheskie aspekty argumentatsii. Astreia.

Ekman, P., \& Friesen, W. (1981). The repertoire of nonverbal behavior: Categories, origins, usage, and coding. In A. Kendon, T. A. Sebeok, \& J. Umiker-Sebeok (Eds.), Nonverbal communication, interaction, and gesture: Selections from Semiotica (pp. 57-106). Mouton Publishers. https: //doi.org/10.1515/9783110880021.57

Kolokol'tseva, T. N. (2001). Spetsificheskie kommunikativnye edinitsy dialogicheskou rechi. Izdatel'stvo Volgogradskogo gosuniversiteta.

Koziarevych, L. V. (2006). Verbal'ni ı̆ neverbal'ni zasoby empatyzatsï̈ dialohichnoho dyskursu (na materiali anhlomovnoï prozy XX stolittia) [Unpublished doctoral dissertation]. Kyïvs'kyı̆ natsional'nyı̆ linhvistychnyı̆ universytet.

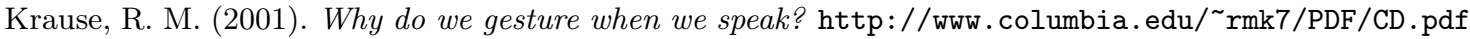

Krĕ̌dlin, G. E., \& Krongauz, M. A. (2015). Semiotika, ili Azbuka obshcheniia: Uchebnoe posobie ( $8^{\text {th }}$ ed.). Flinta.

Kyseliuk, N. P. (2006). Neverbal'ni komponenty komunikatsiï. Naukovyı visnyk Volyns'koho derzhavnoho universytetu: Seriia "Filolohichni nauky", 6, 15-18.

Longman language activator: The world's first production dictionary. (1996). Longman.

Piz, A. (2000). IAzyk telodvizheniu (T. Novikov, Trans.). Ėksmo-Press. http://pedlib.ru/Books/1/0135/ 1_0135-1.shtml

Poyatos, F. (1997a). Aspects, problems and challenges of nonverbal communication in literary translation. In F. Poyatos (Ed.), Nonverbal communication and translation: New perspectives and challenges in literature, interpretation and the media (pp. 17-47). Benjamins. https://doi.org/10.1075/bt1.17. 05 poy

Poyatos, F. (1997b). The reality of multichannel verbal-nonverbal communication in simultaneous and consecutive interpretation. In F. Poyatos (Ed.), Nonverbal communication and translation: New perspectives and challenges in literature, interpretation and the media (pp. 249-282). Benjamins. https://doi.org/10.1075/btl.17.21poy

Selivanova, O. O. (2006). Suchasna linhvistyka: Terminolohichna entsyklopediia. Dovkillia-K.

Soloshchuk, L. V. (2013). Osoblyvosti funktsionuvannia neverbal'nykh komponentiv komunikatsiï v anhlomovnomu dilovomu dialohichnomu dyskursi. Visnyk Kharkivs'koho natsional'noho universytetu imeni V. N. Karazina: Seriia "Romano-hermans'ka filolohiia: Metodyka vykladannia inozemnykh mov", $2013(1051 / 73), 77-82$.

Streek, J., \& Knapp, M. (1992). The interaction of visual and verbal features in human communication. In F. Poyatos (Ed.), Advances in nonverbal communication: Sociocultural, clinical, esthetic and literary perspective (pp. 3-23). Benjamins. https://doi.org/10.1075/z.60.06str

Tuite, K. (1993). The production of gesture. Semiotica, 93(1-2), 83-105. https://doi.org/10.1515/ semi.1993.93.1-2.83

Waite, M. (Ed.). (2012). Oxford paperback thesaurus ( $4^{\text {th }}$ ed.). Oxford University Press. 


\section{Illustrative Material}

Bradbury, M. (1962). Eating people is wrong. Penguin Books.

Bradford, B. T. (1995). Everything to gain. Harper Collins Publishers.

Evans, P. A. (1998). Song in your heart. Headline.

Gonick, J. (1983). Mostly true confessions. Penguin Books.

Harris, G. (1984). The children of the wind. Macmillan.

Harris, J. (2001). Blackberry wine. Black Swan.

Jackson, S. (1959). The haunting of Hill House. Penguin Books.

Kent, A. (1976). Signal - close action! Arrow Books.

Livesey, M. (1990). Homework. Penguin Books.

Rowling, J. K. (1999). Harry Potter and the Sorcerer's Stone. Scholastic.

Rowling, J. K. (2002). Harry Potter and the Chamber of Secrets. Scholastic.

The publication was financed at the authors' expense.

The authors declare that they have no competing interests.

All the authors participated equally in preparing conception and academic editing of this article.

This is an Open Access article distributed under the terms of the Creative Commons Attribution 3.0 PL License (http://creativecommons.org/licenses/by/3.0/pl/), which permits redistribution, commercial and noncommercial, provided that the article is properly cited.

\section{(C) The Authors 2020}

Publisher: Institute of Slavic Studies, Polish Academy of Sciences

Publishing History: Received 2020-05-04; Accepted 2020-07-01; Published 2020-12-23. 